\title{
OPTIMALISASI PERAN PUSTAKAWAN DALAM MEMBENTUK POLA PIKIR MASYARAKAT MELALUI PENDIDIKAN INFORMAL
}

\author{
Rostamaji Korniawan*
}

Pengutipan: Kurniawan, R. (2016). Optimalisasi peran pustakawan dalam membentuk pola pikir masyarakat melalui pendidikan informal. Khizanah Al-Hikmah Jurnal Ilmu Perpustakaan, Informasi, dan Kearsipan, 4(2), 130-139.

*Perumus, perancang, dan pengembang Perpustakaan Kementerian Keuangan

(rostamaji.korniawan@kemenkeu.go.id; rostamaji_k@yahoo.com)

\begin{abstract}
ABSTRAK
Kajian ini memaparkan pemahaman pustakawan terhadap perubahan pola pikir masyarakat. Perubahan pola pikir tersebut akan berdampak kepada peningkatan kehidupan masyarakat, terutama dalam peningkatan kesejahteraan masyarakat. Untuk merubah pola pikir masyarakat, pustakawan berperan dalam memberikan pendidikan, khususnya pendidikan informal, melalui gerakan minat membaca. Kajian ini bertujuan untuk mencari kesamaan persepsi pustakawan terhadap peran mereka dalam merubah pola pikir masyarakat tersebut. Hasil kajian menyimpulkan bahwa pustakawan telah memiliki kesamaan dalam memahami bahwa pendidikan informal melalui gerakan membaca menjadi cara yang tepat untuk membentuk pola pikir masyarakat agar mereka dapat menciptakan usaha yang inovatif dan kreatif. Melalui pendekatan kualitiatif deskriptif dengan bantuan Nvivo dihasilkan kesamaan persepsi para pustakawan tersebut, yaitu kesamaan pustakawan di lingkungan Kementerian Keuangan. Para pustakawan juga memahami bahwa membaca menjadi bagian program pendidikan informal yang diberikan pustakawan kepada masyarakat agar peningkatan kesejahteraan masyarakat dapat ditingkatkan
\end{abstract}

Kata Kunci: Pendidikan Informal, Pustakawan, Perpustakaan Kementerian Keuangan

\section{ABSTRACT}

The paper describes the librarians understanding of the changing of citizens' mindset. Its changing will influence to the enhancement of citizens lives, particularly in citizens welfare. To change the citizens' mindset, librarians play certain roles to educate, for instance in informal education like to lift reading habit. The study is aimed to find the same perceptions among librarians to change citizens' mindset. It is found that the librarians have the same perceptions of understanding that informal education like reading habit program was the good strategy to shape citizens' mindset in order to make them more innovative and creative. In addition, the librarians have also figured out that reading may lead citizens to be more welfare.

Key words: Informal Education, Librarian, Ministry of Finance Library 


\section{PENDAHULUAN}

Ukuran kesejahteraan suatu bangsa selalu menjadi bahan perdebatan di setiap waktu. Perdebatan akan muncul ketika data statistik memperlihatkan angka kesejahteraan yang minim, yang pada umumnya selalu direpresentasikan di dalam perhitungan indeks rasio gini. Indeks rasio gini sendiri adalah indeks yang mengukur perkiraan jumlah kemiskinan yang dialami suatu negara. Selain indeks rasio gini, indeks kebahagiaan juga menjadi salah satu parameter ukuran untuk melihat kesejahteraan suatu daerah.

Di samping indeks rasio gini maupun indeks kebahagiaan, jumlah tingkat pengangguran juga menjadi indikator ekonomi makro untuk melihat tingkat kelayakan rumah tangga dalam memenuhi tingkat kesejahteraannya. Demikian pula dengan akses pendidikan dan pelayanan kesehatan yang juga menjadi indikator ekonomi untuk melihat sampai sejauh mana masyarakat dapat memenuhi kedua pelayanan sosial tersebut. Selain ukuran yang telah disebutkan sebelumnya, kebijakan pemerintah dalam membelanjakan bantuan sosial seperti bantuan operasional sekolah, bantuan langsung tunai ataupun bantuan jaring pengaman sosial (Bong-Joon, 2008) juga merupakan bentuk kebijakan pemerintah dalam mengatasi krisis kesejahteraan yang terjadi di dalam masyarakat.

Salah satu indikator ekonomi, yaitu pendidikan, merupakan salah satu indikator yang dinilai dapat memberikan harapan masyarakat untuk meningkatkan kesejahteraan seseorang. Tahun 2015, jumlah masyarakat Indonesia yang berpartisipasi pada pendidikan tingkat tinggi hanya mencapai 17\%. Hampir sebagian besar masyarakat Indonesia hanya memiliki pendidikan sebatas sampai dengan Sekolah Menengah Atas (SMA). Jumlah tersebut akan lebih mudah ditemui di dalam masyarakat pedesaan di mana mata pencaharian mereka lebih dominan di bidang pertanian. Besarnya jumlah penduduk yang yang tidak memiliki pendidikan formal yang tinggi tersebut mendorong perlu adanya dukungan pemerintah maupun masyarakat untuk meningkatkan kapabilitas masyarakat yang kurang beruntung dalam memperoleh pendidikan formal, khususnya pendidikan tinggi.

Pendidikan merupakan program ataupun kegiatan yang digunakan untuk membentuk pola pikir masyarakat. Dengan pembentukan pola pikir, masyarakat dapat memperbaiki standar kehidupan mereka. Pembentukan pola pikir tersebut akan menjadi bermakna ketika pendidikan sudah tidak bertujuan untuk meningkatkan tingkat kesejahteraan semata. Pendidikan bahkan telah berkembang dengan tujuan pembaharuann dari pola pikir yang telah terbentuk selama ini. Dengan kata lain, pendidikan yang akan diperoleh saat ini digunakan untuk memperbaharui pengetahuan dan keterampilan yang sudah ada.

Sejalan dengan peningkatan kebutuhan dan peningkatan mutu pendidikan, pemerintah terus berupaya menghadirkan sarana maupun prasarana pendidikan yang diinginkan oleh masyarakat. Pendidikan menjadi penting untuk meningkatkan kesadaran setiap masyarakat, seperti apa yang telah dilakukan Steven (2014) ketika melakukan analisa kebijakan pendidikan oleh pemerintah di Hong Kong. Bahkan pendidikan bagi masyarakat juga dinilai mampu untuk memberikan pengaruh yang positif bagi pertumbuhan ekonomi (Afzal et.al, 2013; Subroto, 2013) maupun pengaruh yang positif bagi peningkatan ekonomi individu sekalipun (Javed and Arshad, 2013). Peran pemerintah terhadap pendidikan tidak selalu dibebankan kepada lembaga pemerintah yang menangani perbaikan dan kemajuan pendidikan saja (Hong, 2015). Lembaga pemerintah lainnya bahkan dapat dikatakan memiliki kesempatan untuk menjadi mitra bagi lembaga pemerintah yang menangani masalah pendidikan tersebut. 
Perpustakaan sebagai salah satu lembaga pemerintahan atau unit organisasi pemerintahan yang memiliki tugas dan fungsi penyedia literatur, data, informasi, dan penyimpan sejarah referensi dapat menjadi lembaga atau unit organisasi yang dapat membantu menyebarluaskan pendidikan baik secara langsung maupun tidak langsung. Penyebarluasn $e$-texbook merupakan salah satu cara yang efektif (Yungwei and Jackson, 2014) yang dapat dilakukan perpustakaan untuk memberikan pendidikan kepada masyarakat. Oleh sebab itu, kajian ini akan melihat peran pustakawan dalam mendukung program pemerintah dalam membentuk pola pikir masyarakat guna meningkatkan standar kehidupan mereka. Kurang optimalnya peran pustakawan menjadi perhatian penting dalam kajian ini. Demikian pula dengan keterbatasan peran pustakawan dalam eksistensi pemberdayaan ekonomi masyarakat juga menjadi perhatian kita semua. Keterbatasan peran pustakawan tersebut menjadi pertimbangan untuk mengeluarkan sebuah pertanyaan, sampai sejauh mana pustakawan memahami pendidikan, khususnya pendidikan informal, dalam perubahan pola pikir masyarakat?

\section{KAJIAN LITERATUR}

\section{a. Pendidikan dan Kesejahteraan}

Pendidikan selalu menjadi perhatian lebih dari pemerintah dan masyarakat. Dalam perencanaan dan penyerapan anggaran negara, belanja pendidikan telah menjadi prioritas pemerintah dengan tujuan untuk meningkatkan sumber daya manusia yang ada agar dapat memberikan kontribusi yang berarti dalam pembangunan bangsa. Di dalam amanat Undang - Undang Dasar negara, pendidikan bahkan menjadi suatu hal yang diatur secara hukum. Dalam ketentuan tersebut, pendidikan merupakan hak setiap masyarakat yang harus dipenuhi. Ketentuan ini tentu melandasi keyakinan setiap masyarakat bahwa pendidikan menjadi bagian dari kebutuhan yang tidak terpisahkan seperti halnya kebutuhan - kebutuhan yang lainnya.

Prioritas adanya pemberian pendidikan kepada masyarakat adalah untuk memberikan pengetahuan yang dibutuhkan masyarakat. Dengan pengetahuan, masyarakat dapat mereformasi perilaku, pola pikir, maupun metode untuk mendapatkan kesempatan di dalam memenuhi standar kebutuhan hidup yang mereka harapkan. Namun pendidikan tidak hanya ditujukan untuk memperbaiki kehidupan individu semata. Dengan pendidikan, masyarakat juga diajak secara bersama - sama untuk membangun aspek kekuatan ekonomi bangsa.

Salah satu tolok ukur keberhasilan dalam membangun aspek kekuatan ekonomi bangsa adalah tercapainya kesejahteraan masyarakat. Kesejahteraan sendiri selalu diasumsikan masyarakat sebagai keadaan yang banyak mendapatkan kelimpahan secara material. Adapula individu yang juga berasumsi bahwa kesejahteraan adalah suatu keadaan di mana seseorang telah memiliki kebahagiaan atas keberhasilannya mencapai sesuatu, baik itu sesuatu yang dapt diukur secara material maupun sesuatu yang dilihat dari sisi non materialnya. Pemahaman kesejahteraan sudah lama dikembangkan para ilmuwan pada abad pertengahan ketika sejarah perkembangan kapitalisme ditentang oleh orang - orang yang memiliki pemahaman atas ajaran komunis. Ajaran Marxisme adalah ajaran yang mendorong lahirnya kesejahteraan untuk masyarakat. Timbulnya dorongan untuk mencapai kesejahteraan masyarakat lahir akibat adanya perlawanan dari kaum proletar terhadap kaum kapitalis karena kondisi ekonomi dan sosial yang tidak seimbang pada saat itu.

Ajaran Marxisme mendorong kaum buruh untuk melakukan konfrontasi terhadap kaum kapitalis atas kekuasaan material yang dimiliki oleh kaum kapitalis. Tekanan terhadap kaum buruh yang dinilai kurang manusiawi juga menjadi pemicu timbulnya 
konflik antara kaum kapitalis dan kaum buruh. Situasi ini yang akhirnya melahirkan semangat perjuangan untuk mendapatkan kesejahteraan bagi kaum proletar. Dari hasil pemikiran Karl Marx ini, komunisme yang kemudian bertransformasi menjadi sosialisme telah menggantikan kapitalisme yang dinilai gagal dalam menyejahterakan lapisan masyarakat secara keseluruhan, khususnya masyarakat dari golongan kaum buruh.

Dalam paham komunisme, individu tidak memiliki akses untuk memiliki kekayaan secara penuh. Paham ini menggagas kemakmuran bagi seluruh rakyat melalui pembatasan penggunaan sumber kekayaan secara individu. Komunisme bahkan menghilangkan nilai - nilai religi yang dinilai tidak sejalan dengan pemikiran komunis. Demikian pula dengan keyakinan yang didasari pada pemahaman transedentalisme juga dinilai bukan merupakan bagian dari pemikirian yang sejalan dengan paham komunisme.

Sejak paham komunisme Rusia runtuh, komunisme yang berkembang di di dunia juga mengalami hal yang sama. Gagalnya komunisme di dunia menjadi indikasi bahwa komunisme menjadi sebuah produk yang gagal. Di lain sisi, paham kapitalisme justru menjadi prinsip yang memberikan kontribusi proporsional bagi kebaikan kehidupan ekonomi suatu bangsa. Kebenaran paham kapitalisme didukung oleh keberhasilan beberapa negara yang telah memberikan kesejahteraan kepada masyarakatnya dengan membentuk struktur ekonomi dan sosial yang proporsional. Bangkitnya industrialisasi di beberapa negara di Eropa menjadi contoh idealnya liberalisasi dalam paham kapitalisme. Inggris menjadi salah satu negara Eropa yang berhasil membangun negeri dengan menggunakan paham kapitalisme tersebut. Bagi negara yang masih menggunakan kapitalisme sebagai jalan pemikiran mereka, kedudukan kaum buruh maupun pemilik modal adalah proporsional. Buruh mendapatkan manfaatnya. Demikian pula dengan pemilik modal yang juga mendapatkan manfaatnya sesuai dengan kapasitas yang mereka miliki masing masing. Reformasi kesejahteraan (Abrahamson, 2010), reformasi kualitas sosial (Walker, 2009), reformasi pendidikan (Kiong-Hock, 2000; Nelson, 2006) dan pembangunan kepentingan publik yang nyaman menjadi dasar tercapainya masyarakat yang sejahtra. Bahkan dengan mendukung demokrasi pasar maupun demokrasi kekuasaan negara yang ditunjukkan pada penatausahaan sistem dan tata kelola institusi pemerintahan (Walker and Chack-Kie, 2009; Mai and Mingliang, 2008) yang baik dan institusi serikat pekerja seperti yang dianalisa oleh Se-Hoon (2007), maka kesejahteraan suatu negara dapat direalisasikan.

Perkembangan kapitalisme yang membawa pada liberalisasi sektor ekonomi di dunia telah meluaskan makna kesejahteraan itu sendiri. Liberalisasi menjadi kesepakatan bersama antar negara yang ditandai dengan kebebasan dalam lingkup perdagangan dan investasi. Lambat laun, liberalisasi yang telah berjalan menimbulkan dilema dan akhirnya mendorong timbulnya persaingan usaha yang saling memperebutkan kedudukan dalam memberikan pengaruh. Hegemoni kekuasaan muncul dan menciptakan ketidakadilan bagi negara yang kalah dalam persaingan. Walaupun demikian, liberalisasi juga menyisakan sisi yang positif di mana seseorang dapat menciptakan produk yang memiliki nilai tambah melalui karya yang inovatif dan kreatif Bagi masyarakat yang tidak dapat bersaing dan memiliki banyak kekurangan, situasi ini tentu akan menciptakan kesenjangan dalam strata sosial yang ada. Kesenjangan ini akan menciptakan kemiskinan yang dapat mempengaruhi standar kesejahteraan suatu masyarakat.

Salah satu kesulitan yang akan dihadapi masyarakat yang hidup dalam kemiskinan adalah akses untuk mendapat pelayanan kesehatan maupun pendidikan. Kesulitan ini sering dijumpai di negara berkembang seperti Indonesia. Berbeda dengan negara Barat, lapisan masyarakat yang hidup dalam kemiskinan setidaknya lebih kecil karena 
social quality masyarakat mereka cenderung lebih baik. Chui-Man and Wai-Kam (2009) dalam penelitiannya menyimpulkan bahwa untuk mengurangi kesenjangan antara negara Barat (western countries) dan negara non Barat (non-western countries), negara negara non Barat tersebut perlu belajar dari Hong Kong. Pendidikan masyarakat Hong Kong dinilai dapat menjadi acuan bagi negara-negara berkembang untuk memperbaiki sumber daya manusia yang ada.

Walaupun demikian, bagi masyarakat yang tetap berjuang untuk mendapatkan pendidikan dengan masih banyaknya keterbatasan yang mereka miliki, hal ini tentu akan menjadi sebuah kesempatan yang memiliki value yang sangat tinggi. Sementara efektifitas pendidikan sendiri juga masih menjadi konsumsi perdebatan masyarakat. Salah satu kritikan terhadap efektifitas pendidikan diutarakan Kee-Cheok and Kiong-Hock (2016) karena output dari pendidikan belum memberikan hasil yang signifikan. Tidak hanya itu, liberalisasi pendidikan yang berkembang pada masa globalisasi dan kebebasan ini juga telah menciptakan komersialisasi dan politik pendidikan (Putra, 2016) yang memberikan cost yang tinggi bagi masyarakat. Bagi masyarakat yang memiliki keterbatasan, hal ini tentu akan menjadi pertimbangan. Namun demikian, pendidikan informal dapat menjadi alternatif pilihan mereka melihat masih banyaknya sarana, media, maupun cara untuk mendapatkan pengetahuan yang mereka harapkan.

\section{b. Pendidikan Informal}

Pendidikan informal memiliki manfaat yang sama dengan pendidikan formal. Pemerintah selalu turut serta dalam membangun pola pendidikan di Indonesia. Baik pendidikan formal maupun pendidikan informal, keduanya merupakan bagian dari pandangan kebijakan pemerintah dalam membangun sistem pendidikan yang dapat menyesuaikan diri. Setelah pemerintahan
Indonesia melakukan reformasi di bidang pendidikan, masyarakat yang mengalami keterbatasan untuk mendapatkan pendidikan setidaknya sudah mulai berkurang. Program bantuan pendidikan telah menjadi prioritas pemerintah untuk mengembangkan potensi sumber daya manusia yang ada. Meskipun demikian, masyarakat yang masih memiliki tingkat pendidikan yang rendah maupun masyarakat yang masih memiliki keterbatasan dalam akses informasi yang berkembang cepat saat ini masih tetap memerlukan pembaharuan wawasan agar kompetensi yang mereka miliki dapat terus ditingkatkan.

Salah satu pendidikan yang jarang mendapatkan perhatian pemerintah adalah wujud pendidikan informal. Dilihat dari sisi manfaatnya, pendidikan informal dapat menjadi penunjang masyarakat dalam memperbaharui pendidikan formal yang telah mereka miliki selama ini. Pendidikan informal akan menjadi unsur pembaharu pola pikir masyarakat. Perubahan pola pikir yang diproses melalui kegiatan membaca sebagai salah satu aktivitas yang menjadi bagian dari program pendidikan informal tersebut.

Aktivitas membaca dapat dilakukan di mana saja. Apabila dilihat dari sisi lokasi, perpustakaan adalah tempat yang ideal bagi masyarakat dalam membantu mewujudkan pelaksanaan program pendidikan informal. Mewujudkan pendidikan informal pada dasarnya dapat dilakukan oleh semua pihak, termasuk pemerintah. Dalam kebijakan mendukung pendidikan formal, pemerintah setidaknya telah berkontribusi dalam meningkatkan mutu pendidikan formal, baik melalui peningkatan mutu fasilitas pendidikan, peningkatan mutu bahan ajar maupun peningkatan mutu masyarakat yang menerima pendidikan tersebut. Agar pendidikan dapat menyentuh semua pihak, maka pendidikan informal dapat menjadi salah satu pilihan dalam memajukan dunia pendidikan. 
Perpustakaan yang dikelola pemerintah dapat menjadi pendukung program pemerintah dalam menyebarluaskan pendidikan informal tersebut. Pendidikan informal yang selalu menjadi rujukan pemerintah adalah pendidikan pada institusi pendidikan non linear, seperti pendidikan penyesuaian ijasah. Namun aktivitas membaca adalah salah satu aktivitas yang dapat diklasifikasikan sebagai bentuk program pendidikan informal. Diprogram inilah peran pustakawan akan menjadi optimal. Dengan membaca, masyarakat dapat berpikir secara kritis (Shihab, 2011) dan mampu memperbaharui keadaan berdasarkan pengetahuan dan situasi yang berkembang disekitarnya. Untuk mengetahui persepsi pustakawan terhadap kegiatan program tersebut, pembahasan berikutnya akan melihat hasil observasi dan intervew terhadap pustakawan yang ada dilingkungan Kementerian Keuangan, khususnya pustakawan yang berada di lingkungan Sekretariat Jenderal Kementerian Keuangan.

\section{METODOLOGI PENELITIAN}

Persepsi pustakawan dalam kajian ini akan menjawab manfaat pendidikan, khususnya pendidikan informal bagi masyarakat yang sudah tidak memiliki kesempatan untuk mendapatkan pendidikan formal yang lebih tinggi (Nagaraj et.al, 2016) yang pada akhirnya akan digunakan untuk mendukung peningkatan kesejahteraan masyarakat. Selain itu, kajian ini juga membatasi ruang lingkup pengamatan di mana perpustakaan Kementerian Keuangan menjadi obyek penelitian yang akan diamati. Persepsi pustakawan dalam mendukung program pendidikan informal dan kesejahteraan bangsa akan menjadi poin penting dalam kajian ini. Kajian ini akan menggunakan pendekatan kualitatif deskriptif dengan bantuan Nvivo. Bahasan selanjutnya adalah penjelasan mengenai pendidikan dan hubungannya dengan kesejahteraan. Setelah itu bahasan dilanjutkan dengan menjelaskan wujud dari pendidikan informal yang dilakukan oleh pustakawan. Pada subbab pembahasan berikutnya, persepsi pustakawan
Kementerian Keuangan menjadi bahasan yang utama untuk mengetahui pemahaman mereka terhadap pembentukan pola pikir masyarakat dari pendidikan informal bagi kesejahteraan. Kajian ini akan ditutup dengan kesimpulan.

\section{HASIL PENELITIAN DAN PEMBAHASAN}

\section{a. Persepsi Pustakawan Kementerian Keuangan}

Pustakawan sebagai tenaga fungsional yang ahli dalam bidang pengelolaan literatur tidak hanya mengembangkan dirinya pada pengelolaan literatur semata. Dalam rincian tugas dan fungsi yang dimiliki, pustakawan juga memiliki tugas maupun fungsi sebagai seorang pembimbing. Bimbingan yang mereka berikan tentunya mengacu kepada pelayanan pemberian informasi kepada stakeholders perpustakaan.

Pemberian pelayanan pendidikan dari pustakawan merupakan wujud ril dari pelayanan pemerintah dalam meningkatkan mutu sumber daya manusia di Indonesia. Dengan pemberian layanan pendidikan tersebut, masyarakat yang memperoleh pendidikan melalui para pustakawan diharapkan mampu memperbaharui pola pikir yang mereka miliki saat ini, khususnya pengetahuan dalam pengembangan dan perbaikan tingkat kesejahteraan masyarakat yang ada. Agar fungsi ini dapat memberikan hasil yang optimal, pustakawan memerlukan pemahaman yang sejalan terhadap pelayanan pendidikan, khususnya pendidikan informal, dan kesejahteraan masyarakat.

Dukungan pendidikan yang diberikan dari para pustakawan saat ini sudah sangat tepat melihat peran pemerintah yang semakin menunjukkan niatnya untuk melakukan perubahan. Dengan berdirinya beberapa perpustakaan di daerah juga mendukung peran pemerintah yang diwakili oleh para pustakawan untuk dapat memberikan kontribusi positif bagi peningkatan nilai tambah perpustakaan. Pemberdayaan peran 
pustakawan dalam pendidikan yang mengarah kepada pembentukan masyarakat yang inovatif untuk memperbaiki tingkat kesejahteraannya adalah suatu target pembaharuan fungsi pustakawan agar pemerintah dapat beradaptasi secara cepat dalam membangun karakter bangsa yang membangun.

Dalam Tabel 1 di dalam lampiran memperlihatkan jumlah perpustakaan umum di setiap provinsi yang ada di Indonesia. Jumlah perpustakaan terbanyak berada di pulau Jawa, yaitu Provinsi Jawa Timur, Provinsi Jawa Barat, dan Provinsi Jawa Tengah. Masing-masing provinsi memiliki 299, 266, dan 105 perpustakaan umum. Jumlah perpustakaan umum tersebut tidak mencakup keberadaan perpustakaan lainnya yang dimiliki pemerintah maupun swasta. Keberadaan perpustakaan di lingkungan institusi pendidikan juga belum masuk ke dalam angka statistik jumlah perpustakaan umum daerah. Demikian pula dengan keberadaan perpustakaan yang dimiliki instansi pemerintah, seperti perpustakaan di lingkungan Kementerian Keuangan. Perpustakaan di Kementerian Keuangan sendiri memiliki beberapa perpustakaan yang tersebar di beberapa unit eselon I. Dalam kajian ini, hanya perpustakaan yang berada di lingkungan Sekretariat Jenderal saja yang menjadi spotlight. Keberadaan perpustakaan Kementerian Keuangan di lilngkungan Sekretariat Jenderal menjadi pilihat melihat format dan ragam aktivitas yang mereka miliki. Oleh sebab itu, persepsi pustakawan di perpustakaan Sekretariat Jenderal Kementerian Keuangan akan menjadi pilihan yang unik dalam memahami persepsi pendidikan informal yang lebih mutakhir.

Perpustakaan Kementerian Keuangan di lingkungan Sekretariat Jenderal memiliki koleksi lebih dari 10.000 bahan yang terdiri dari koleksi buku, CD, maupun bahan literatur lainnya. Perpustakaan ini memiliki struktur organisasi yang mengikuti struktur organisasi pemerintah pada umumnya. Di dalam struktur organisasinya, perpustakaan ini memiliki lima orang petugas pelayanan perpustakaan di mana salah satunya berfungsi sebagai manajer madya. Aktivitas yang dilakukan para pustakawan tidak jauh berbeda dengan aktivitas yang dilakukan oleh para pustakawan lainnya. Perpustakaan Kementerian Keuangan yang menjadi obyek pengamatan ini berkedudukan di bawah Biro Komunikasi dan Layanan Informasi yang menjadi unit eselon II di lingkungan Sekretariat Jenderal, Kementerian Keuangan. Sesuai dengan Peraturan Menteri Keuangan yang baru, kedudukan Perpustakaan Kementerian Keuangan tersebut diatur di dalam PMK Nomor 234/PMK.01/2015.

Kegiatan atau aktivitas yang diselenggarakan Perpustakaan Kementerian Keuangan setidaknya memiliki nuansa kabaharuan yang kreatif dan inovatif. Bincang pagi, bedah buku, atau festival literasi adalah beberapa acara yang dapat memberikan keceriaan bagi para stakeholders perpustakaan. Tema-tema yang dihadirkan pun cukup memberikan keterbukaan dan kekeluargaan. Hanya saja, beberapa kegiatan yang dilakukan masih berada di lingkungan Kementerian Keuangan. Secara struktur, tugas, dan fungsi, perpustakaan ini memang berguna untuk memberikan pelayanan kepada pegawai sebagai stakeholders yang utama. Keterbatasan anggaran dan pola birokrasi dalam mengambil keputusan ketika menyelenggarakan suatu kegiatan membuat inovasi dan kreatifitas pustakawan dalam bertugas menjadi terbatas. Namun keterbatasan tidak menghambat pustakawan untuk tetap memberikan dukungan yang optimal untuk mengembangkan organisasi maupun membangun bangsa dengan pemberdayaan imajinasi dan pemikiran pustakawan yang kreatif.

Dalam obervasi yang dilakukan di perpustakaan ini, para pustakawan memiliki dedikasi yang sangat tinggi terhadap tugas dan fungsi yang telah diberikan kepada mereka. Observasi partisipasi langsung ini 
kemudian ditingkatkan dengan mengajukan pertanyaan kepada para pustakawan. Dalam pertanyaan tersebut, kajian ini mempertanyakan pemahaman mereka mengenai 1) makna kesejahteraan, 2) pendidikan informal, dan 3) membaca sebagai wujud dari pendidikan informal. Mewujudkan kesejahteraan adalah proxi dari perubahan pola pikir masyarakat melalui pendidikan informal yang dijalankan dari aktivitas membaca. Dengan membaca, masyarakat diharapkan mampu membuka pemikiran untuk dapat mengendalikan perilaku dan merubahnya untuk mewujudkan kesejahteraan yang mandiri.

Dari pengajuan 3 pertanyaan tersebut, kami melihat adanya kesamaan persepsi mengenai kesejahteraan dan hubungannya antara peran pustakawan dalam pelayanan pendidikan informal dengan kesejahteraan masyarakat. Kesimpulan ini didasari dari persepsi tiga pustakawan yang kami kaji dengan alat bantu Nvivo. Dalam proses analisa teks yang diperoleh dari hasil interview tertutup tersebut, pengkodean dilakukan dengan membuat nodes korelasi antara pendidikan dan kesejahteraan. Secara keseluruhan, pustakawan memahami bahwa kesejahteraan merupakan situasi kehidupan seseorang yang dapat diukur secara materi maupun non materi. Salah satu pustakawan, yaitu pustakawan 3 mengemukakan pendapatnya mengenai kesejahteraan yang tertera di bawah ini:

"kesejahteraan merupakan kondisi dimana kita merasa berkecukupan atas apa yang kita miliki. Kesejahteraan tidak selalu ditandai dengan harta yang banyak ataupun kekuatan finansial yang besar. Selain itu kebutuhan pokok kita juga sudah 'cukup' terpenuhi."

Sementara itu, pemahaman pustakawan tersebut terhadap peran pendidikan informal bagi kesejahteraan masyarakat juga telah menjadi pemahaman yang positif bahwa pendidikan informal yang dilakukan dengan menarik minat membaca merupakan stimulus yang bermanfaat dalam meningkatkan kesejahteraan masyarakat.
"Saya setuju pendidikan informal dapat meningkatkan kesejahteraan. Pendidikan informal justru dapat membekali kita dengan skill siap pakai yang akan dapat langsung kita gunakan untuk meningkatkan kualitas hidup kita. dan yang paling penting pendidikan informal dapat mengarahkan kita ke bidang sesuai passion kita."

Baik pendidikan formal maupun informal, keduanya merupakan pendidikan yang diberikan secara terbuka (Merriam, 2000) yang bertujuan untuk meningkatkan pengetahuan.

"Apapun konteksnya apakah itu pendidikan informal ataupun formal, selama ada aktivitas menyerap ilmu baru khususnya melalui membaca otomatis dapat meng-upgrade pengetahuan."

Kesimpulan dari kajian kualitatif yang melihat persepsi pustakawan terhadap perubahan pola pikir masyarakat setelah melakukan kegiatan membaca sehingga berdampak kepada ekonomi dan kesejahteraan mereka adalah pemahaman yang sejalan dari para responden tersebut. Mereka melihat bahwa pendidikan informal memiliki manfaat yang baik dalam menumbuhkembangkan inisiatif masyarakat dalam memperbaiki pola hidup masyarakat. Dengan pemahaman yang sejalan ini, maka program pendidikan informal para pustakawan melalui gerakan minat membaca kepada masyarakat dapat dilaksanakan. , Pustakawan cukup memberikan motivasi kepada masyarakat agar membaca dapat menjadi konsumsi sekunder di lingkungan masyarakat. Hal ini dapat menjadi bentuk apresiasi kepada para pustakawan, selain merubah stigma yang negatif terhadap kurang optimalnya kinerja para pustakawan selama ini. Stigma negatif yang berkembang tersebut selalu menempatkan para pustakawan sebagai tenaga fungsional yang terbuang. Dengan melihat potensi ini maka secara bertahap, peran pustakawan akan optimal dan memberikan nilai tambah ataupun selling point yang lebih menarik. 


\section{KESIMPULAN}

Dari pemaparan kajian di atas dapat disimpulkan bahwa pemahaman pustakawan terhadap kesejahteraan masyarakat sudah sejalan. Sejalan dalam arti bahwa pustakawan memahami kesejahteraan dicapai masyarakat setelah mereka mendapatkan pendidikan yang dibutuhkan. Pendidikan yang dibutuhkan diwujudkan dengan penyelenggaraan program pendidikan informal melalui gerakan menarik minat membaca masyarakat Gerakan minat membaca tersebut diharapkan mampu merubah pola pikir masyarakat. Membaca pada dasarnya merupakan aktivitas yang menarik yang diajarkan pertama kali pada institusi pendidikan formal. Namun, membaca juga dapat menjadi aktivitas pendidikan informal ketika masyarakat yang sudah dapat membaca memperbaharui kembali pengetahuan mereka dengan memberikan ragam literatur yang ada di dalam perpustakaan. Hal ini ditujukan untuk meningkatkan pengetahuan maupun skill masyarakat.

Kajian ini belum menyentuh persepsi pustakawan secara keseluruhan. Banyaknya pustakawan yang tersebar di berbagai daerah menjadi kendala dalam menyamakan persepsi pustakawan yang ada. Agar dapat lebih memberikan hasil yang lebih baik, kajian harus terlibat dalam pelayanan perpustakaan yang berlokasi di daerah. Koleksi, cost and benefit pustakawan, lokasi, manajemen organisasi perpustakaan, maupun kapasitas sumber daya manusia perpustakaan dapat menjadi kajian yang lebih komprehensif dalam merekomendasikan perpustakaan dan pustakawan sebagai pionir dalam membangun kesejahteraan masyarakat melalui pendidikan bangsa.

\section{DAFTAR PUSTAKA}

Abrahamson, Peter. "European Welfare States Beyond Neoliberalism Toward the Social Investment State." Development
And Society, vol. 39, no. 1, 2010, pp. 61-95.

Afzal, Muhammad, Arshed, Muhammad Gulfam, and Sarwar, Kafeel. "Education, Helth, Food Inflation And Economic Growth In Pakistan." Pakistan Economic and Social Review, vol. 51, no. 2, 2013, pp. 109-138.

Bong-Joon, Yoon. "Welfare Programs For The Global Era: Lesson From The U.S. Experience." Journal of Economic Development, vol. 33, no. 2, 2008, pp. 85-106.

Chui-Man, Ruby Chau and Wai-Kam, Sam $\mathrm{Yu}$. "Social Quality and the Social Harmony Campaign in Hong Kong." Development And Society, vol. 38, no. 2, 2009, pp. 277-295.

Javed, Zahoor Hussain and Arshad, Nafeesa. "Rate of return to Investment in Education: A Case Study of Faisalabad." Journal of Asian Business Strategy, vol. 3, no. 8, 2013, pp. 192-199.

Jieun, Hong. "Effects of Education Policies and Institutions on Student Performance." Seoul Journal of Economics, vol. 28, no. 1, 2015, pp. 85105.

Kee-Cheok Cheong and Kiong-Hock Lee. "Malaysia's Education Crisis-Can TVET Help?." Malaysian Journal of Economic Studies, vol. 53, no. 1, 2016, pp. 115134.

Kiong-Hock Lee. "Reforming Education for the Global Information Economy." Malaysian Journal of Economics Studies, vol. 37 , no. 1 and 2, 2000, pp. 53-91.

Mai, Lu and Mingliang, Feng. "Reforming the Welfare System in the People's Republic of China." Asian Development Review, vol. 25, no. 1 and 2, 2008, pp. 58-80.

Merriam, Sharan B. "Open Learning and Adults Education in the United States." Korea Observer, vol. 31, no. 2, 2000, pp. 219-260.

Nagaraj, Shyamala, Kiong-Hock Lee, KimLeng Goh, and Nai-Peng Tey. "Malaysian Adolescents Not in School: The Nexus of Education, Work and 
Gender." Malaysian Journal of Economic Studies, vol. 53, no. 1, 2016, pp. $87-113$.

Nelson, Matthew J. "Muslims, Markets, And The Meaning of A "Good" Education In Pakistan." Asian Survey, vol. 46, no. 5, 2006, pp. 699-720.

Putra, Galih R.N. Politik Pendidikan. Yayasan Pustaka Obor Indonesia, Jakarta, 2016.

Se-Hoon, Ko. "Reinventing the Korean Welfare System: Still a Case for "Politics Against Market'?." Korea Observer, vol. 38, no. 2, 2007, pp. 191-223.

Shihab, Ibrahim Abu. "Reading As Critical Thinking." Asian Social Science, vol. 7, no. 8, 2011, pp.209-218.

Steven, Hung Chung Fun. "The Genealogical Analysis of the HKSAR's Civic Education Policy." Asian Education and Development Studies, vol. 4, no. 2, 2015, pp.204-220.

Subroto, Waspodo Tjipto. "Entrepreneurship Development Course To Foster Character Merchandise In Support Economic Growth." Asian Economic and Financial Review, vol. 3, no. 6, 2013, pp. $762-771$.

Walker, Alan. "The Social Quality Approach: Bridging Asia and Europe." Development And Society, vol. 38, no. 2, 2009, pp. 209-235.

Walker, Alan and Chack-Kie, Wong. "The Relationship Between Social Policy and Economic Policy: Constructing the Public Burden of Welfare in China and the West." Developemen And Society, vol. 38, no. 1, 2009, pp. 1-26.

Yungwei Hao and Jackson, Kathy. "Student Satisfaction Toward e-Textbooks in Higher Education." Journal of Science and Technology Policy Management, vol. 5, no. 3, 2014, pp. 231-246. 